\title{
Uptake of Colostral Immunoglobulins by the Com- promised Newborn Farm Animal
}

\author{
By P.T. Sangild
}

Division of Animal Nutrition, Department of Animal Science and Health, The Royal Veterinary and Agricultural University, Frederiksberg, Denmark.

\begin{abstract}
Sangild PT: Uptake of colostral immunoglobulins by the compromised newborn farm animal. Acta vet. scand. 2003. Suppl. 98, 105-122. - Neonatal mortality is very high in farm animals $(\sim 10 \%)$ and disease resistance is greatly influenced by an adequate passive immunisation just after birth. In piglets, foals, calves and lambs, the intestinal absorption of immunoglobulins from their mother's colostrum occurs mainly by a nonspecific endocytosis of macromolecules, but the details of the absorption process, and the mechanisms regulating its cessation after 1-2 days of colostrum exposure, remain poorly understood. In both normal and 'compromised' (premature, growth-retarded, hypoxic, lethargic) newborn farm animals, the intestinal capacity to absorb macromolecules is influenced by both diet- and animal-related factors. Thus, macromolecule uptake is severely reduced in response to premature birth and when macromolecules are to be absorbed from diets other than species-specific colostrum. On the other hand, fetal growth retardation, in vitro embryo production, or a stressful birth process are unlikely to reduce the ability of the intestine to absorb immunoglobulins from colostrum. More knowledge about the diet- and animal-related factors affecting intestinal immunoglobulin uptake will improve the clinical care of 'compromised' newborn farm animals. The present text gives a brief introduction to the process of intestinal immunoglobulin absorption in large farm animals and describe some recent results from the author's own studies in pigs, calves and lambs.
\end{abstract}

intestinal closure; immunoglobulin; birth; stress; cortisol; colostrum; cesarean section; growth retardation; in vitro embryo production.

\section{Intestinal macromolecule uptake and gut closure in farm animals}

A large neonatal mortality in farm animals indicates that the neonates in these species often fails to adapt adequately to postnatal life. Neonatal vitality often shows a positive correlation with the degree of passive immunisation (Butler 1979, Varley 1992, Wittum \& Perino 1995), and circulating immunoglobulins, particularly immunoglobulin G (IgG), constitute a key element in the general host defence against environmental antigens. Before birth, the fetus is well protected from antigens by the protective barrier of the placenta. Just after birth, the newborn must be able to respond immunologically to a massive invasion of potentially harmful antigens and microorganisms from the surrounding environment. The innate immune defence is immature at the time of birth and the specific immune system non existent. Passive immunisation from the mother is required until the active immune system is fully developed (Kim 1975, Butler 1998, Bailey et al. 2001, Sinkora et al. 2003). Humans and some other species are born with passive immunity in the form of maternal immunoglobulins transferred across the placenta before birth. In contrast, the newborns of large farm animals (calves, 
piglets, foals, lambs) are dependent on the intestinal transmission of immunoglobulins and other immune modulating factors present in colostrum (Butler, 1979, Baintner, 1986). Besides immunoglobulins, colostrum contains lymphocytes, cytokines, nucleotides and various growth factors which may affect the development of the immune system postnatally (Blum \& Baumrucker 2002, Boutinaud \& Jammes 2002, Schlimme et al. 2002).

The ability of intestinal cells to take up macromolecules, including immunoglobulins, by endocytosis and to transport these molecules intact across the epithelium into the blood stream is one of the most striking and unique characteristics of the developing intestine. In the large farm animals, this ability ceases within the first day or two after birth by a process known as "intestinal closure". In other species, intestinal closure is delayed until several weeks after birth (rat, mouse, ferret) (Clarke \& Hardy 1970, Baintner 1986). In humans, only the fetal small intestine has the characteristics required for the uptake of intact immunoglobulins (Israel et al. 1993).

In the pig, intestinal closure begins about 6-12 $\mathrm{h}$ after feeding colostrum and progresses rapidly thereafter to completion at 24-36 $\mathrm{h}$ (Weström et al. 1984, 1985). If animals are fasted for a period after birth (Klobasa et al. $1990,1991,1994)$ or if they are fed parenteral nutrients in stead of luminal nutrients (Mehrazar et al. 1993), the period of macromolecule transfer ("the pre-closure period") is prolonged up to several days. The signals inducing closure vary among species but may involve both colostral and systemic factors as well as the maturity of the gut epithelium itself (Clarke \& Hardy 1971, Smith \& Jarvis 1978, Baintner 1986). For instance, glucocorticoids appear to reduce the capacity for and duration of macromolecule transfer in suckling rats (Daniels et al. 1973a, 1973b) but have the op- posite effect in newborn lambs (Hough et al. 1990) and pigs (Sangild et al. 1993).

Until now, the predominent view in the literature has been that the intestinal macromolecule uptake capacity is a fundamental characteristic of an immature epithelium and that a major part of this ability is simply due to the fact that the epithelium is "leaky" and allows greater transport of all large molecules, not only immunoglobulins (Weaver \& Walker 1989). This opinion is supported by the observation that a limited macromolecule transfer takes place across the intestine in infants, despite the fact that passive immunity is aquired in utero via the trans-placental passage of immunoglobulins. Quantitatively, the absorption of intact proteins in human neonates is very low, compared with that in newborn farm animals, and it decreases with advancing fetal and postnatal age (Jacobsson et al. 1986). Human infants delivered prematurely therefore have a greater ability to absorb globulins from the gut than those born at term (Roberton et al. 1982).

As we shall see in the following, the conditions for absorption of globulins in farm animals involve much more than just the presence of a "leaky epithelium" around birth. Although the epithelium of the fetus and newborn may be more permeable for the ions (sodium, chloride) and small molecules (lactulose, monosaccharides) generally used to assess intestinal permeability this does not mean that the epithelium allows transfer of immunoglobulins. The different groups of molecules are transported by completely different mechanisms across the epithelium. In this review, we shall document that the ability of the intestinal enterocytes to absorb large amounts of immunoglobulins (and other macromolecules) by endocytosis is a highly specialized process that develops close to term and then disappears shortly after birth in response to enteral feeding. The rapid developmental changes in transport before and after 
birth contributes to the fact that only small deviations from normal physiological conditions at birth may reduce the intestinal capacity to absorb immunoglobulins. Impaired passive immunisation may lead to compromised disease resistance, both short-term and long-term (Varley et al. 1992, Wittum \& Perino 1995, Gomez et al. 1998).

Intestinal selectivity exists among the IgGs from different species (Frenyo et al. 1987, Jensen et al. 2001) and absorption does not appear to occur entirely by non-specific endocytosis of macromolecules. A preference to transport species-specific IgG from the gut lumen to the circulation, independently of diet, could be due to the presence of specific IgG receptors on intestinal enterocytes, similar to the $\mathrm{F}_{\mathrm{c}}$-receptors known to exist on the brush-border membrane of enterocytes in young rodents (Martin et al. 1997) and in humans during fetal life (Israel et al. 1993). So far an $\mathrm{F}_{\mathrm{c}}$-receptor has not been identified in the intestine of piglets or calves (Staley \& Bush 1985, Pakkanen \& Aalto 1997).

The degree of passive immunisation after colostrum feeding, depends not only on the intestinal capacity to absorb large molecules, but also on the availability of colostrum and its immunoglobulin concentration. These factors are subject to a lot of individual variation and may be affected by time and mode of delivery, breed and parity of the mother. Detailed information on this can be obtained from other sources (Klobasa \& Butler 1987, Jackson et al. 1995, Weaver et al. 2000). In the present review we shall focus exclusively on factors related to the newborn and its intestinal capacity to absorb immunoglobulins.

\section{Diet-related factors affecting intestinal macromolecule uptake}

Artificial rearing of newborn animals often requires the use of suitable alternatives to mother's colostrum, and milk substitutes must have a nutritional composition that match the biological needs of the neonate. Colostrum also contains specific bioactive factors (hormones, growth factors) required for the enterocytes to function and develop normally. A series of recent studies indicate that such nutrient-independent factors in colostrum exert distinct effects on the immature enterocyte and its ability to digest and absorb nutrients (Burrin et al. 1995, Xu 1996). Such factors will be absent in most colostrum substitutes. When artificial diets are used to nourish neonates that experience an inadequate adaptation to postnatal life (e.g. premature or growth-retarded neonates), the composition of the diet (nutrients, bioactive factors) is particularly important for optimal survival and growth.

Feeding bovine colostrum to newborn pigs, without added porcine immunoglobulins, is associated with reduced survival (McCallum et al. 1977, Drew \& Owen 1988, Gomez et al. 1998). Nevertheless, survival is clearly better than in pigs fed a milk replacer completely devoid of immunoglobulins (Gomez et al. 1998). Since the antigen specificity of immunoglobulins determines the degree to which they provide immunological protection, it is not surprising that bovine immunoglobulins cannot provide notable passive immunity against pig pathogens. Regardless, the results show that colostrum per se may contain nutrients and bioactive components that have a positive effect on gut maturation and disease resistance in a species-independent manner. This hypothesis is supported by the documented positive effects of feeding bovine colostrum to pigs with weaningassociated diarrhoea (Jiang et al. 2000) or humans showing drug-induced intestinal disease (Playford et al. 2001).

It has been tested whether the provision of specific passive immunity in neonatal animals can be secured by the addition of purified im- 


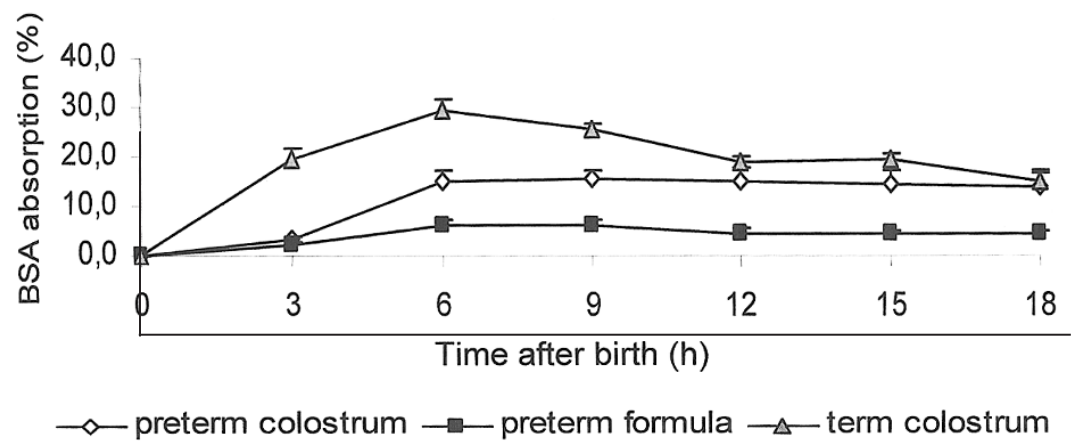

Figure 1. Concentrations of bovine serum albumin (BSA, a macromolecule marker, means \pm SEM) in plasma of newborn preterm or term pigs in response to feeding either milk replacer (formula) or sow's colostrum (15 $\mathrm{mL} / \mathrm{kg} / 3 \mathrm{~h}$ ) containing BSA (20 g/L) in the first feeding at $0 \mathrm{~h}$ (Sangild et al., unpublished observations). Premature pigs show reduced capacity to absorp BSA from colostrum, compared with term pigs, and feeding a milk replacer in stead of colostrum reduce this capacity further.

munoglobulins or crude plasma proteins to "artificial diets" (colostrum or milk from another species, artificial milk replacers). The degree of passive immunisation may be low however, because intestinal macromolecule absorption is greatly influenced by the composition of the fluid in which the immunoglobulins are dissolved (Carlsson et al. 1980, Weström et al. 1985, Jensen et al. 2001). Although the newborn pig preferentially absorbs porcine $\mathrm{IgG}$, relative to bovine IgG and other protein macromolecules, it appears that porcine colostrum is required to secure a normal macromolecule absorption during the first $24 \mathrm{~h}$ after birth. Feeding a non species-specific colostrum, milk, milk replacer or an electrolyte solution is associated with a significantly reduced uptake capacity and/or earlier cessation of macromolecule transport (Klobasa et al. 1991, 1994, Jensen et al. 2001). This must be taken into account when immunoglobulins are included into diets other than colostrum from the same species in artificial rearing of newborn farm animals. This problem is illustrated by the data shown in Figure 1 where BSA has been used as a marker for macromolecules in premature pigs fed either colostrum or a milk replacer. Hence, species-specific, nutrient-independent factors are present in colostrum and they facilitate the endocytosis of large molecules by the neonatal intestine. This diet-related stimulation of immunoglobulin uptake may take place via an enhanced luminal stability of the immunoglobulins following ingestion of colostrum which contains large amounts of protease inhibitors (Weström et al. 1985). Stimulation of uptake could also result from the direct effects of colostrum-specific nutrients, growth factors and hormones affecting the endocytotic capacity of developing enterocytes.

\section{Premature birth}

Premature labour in the large farm animals is often associated with clinical complications in the pregnant mother and/or the developing fetus. It is most commonly observed as a response to a clinical or sub-clinical state of infection, but premature birth may also occur spontaneously, without any obvious etiology. In case of viral or bacterial infection, the associated production of toxins directly or indirectly leads to the maternal, placental and/or fetal endocrine 


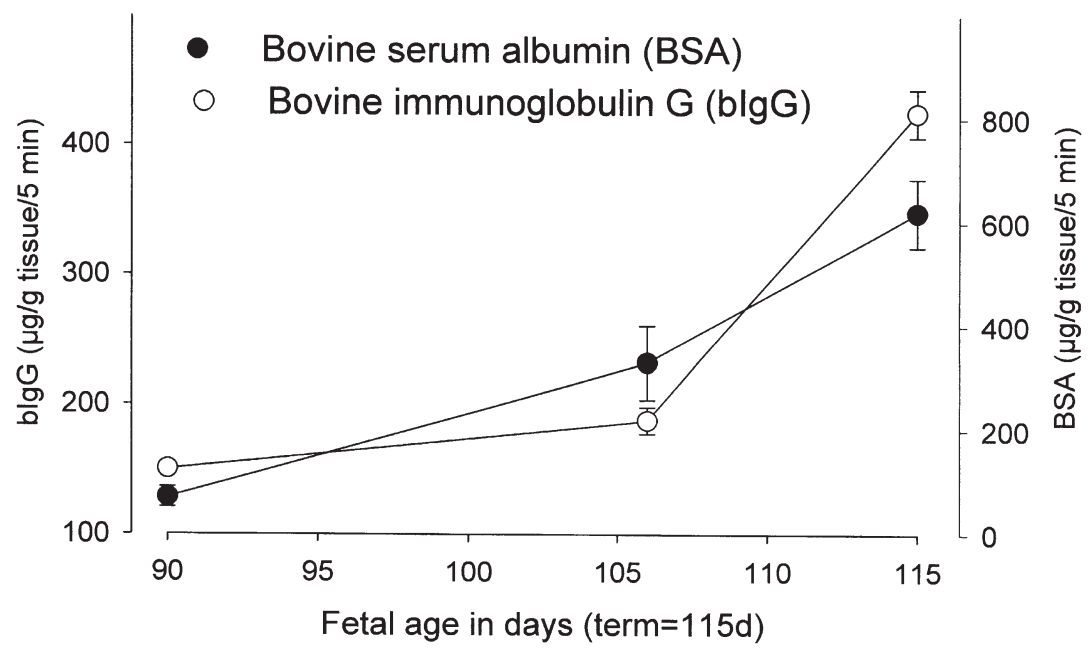

Figure 2. Development of the in vitro capacity of pig intestinal tissue to take up non-specific protein macromolecules before birth. The tissue uptake (means \pm SEM) of bovine immunoglobulin (bIgG) and bovine serum albumin (BSA) was low at 90 days gestation but both increased rapidly, and in parallel, during the weeks before term (115 days).

changes required to initiate the labour process. An inflammatory response, such as that reflected by elevated production of interleukins, has been shown to play a role in many cases of preterm labour (Coleman et al. 2001).

Preterm birth may be associated with decreased uptake capacity, if the ability to absorp large molecules develops close to term. A series of studies in sheep, pigs and calves support this hypothesis. Hence, the capacity for intact protein absorption is severely depressed in piglets, calves and lambs delivered prematurely compared with those born at term (Johnston \& Stewart 1986, Hough et al. 1990, Sangild et al. 1997, 2002b) (see also Figure 1). These studies do not however, provide direct evidence that it is the lack of intestinal maturation that is responsible for the lowered immunoglobulin transfer. It cannot be excluded that the altered metabolic or endocrine parameters related to preterm birth prevent the intestinal enterocytes in reaching their full endocytotic potential. Such altered parameters in premature newborns include lowered blood oxygen, $\mathrm{pH}$, glucose and cortisol levels, due to the immaturity of organ structure and function, compared with animals born at normal term (Sangild et al. 1996, 1997). Nevertheless, studies on isolated intestine in vitro suggest that the capacity of the pig intestinal cells to absorb immunoglobulins is indeed much lower in the last weeks before term than at full term (Sangild et al. 2002a). Figure 2 illustrates that in vitro, the capacity of pig intestinal tissue to take up two bovine macromolecules, immunoglobulin $\mathrm{G}$ and serum albumin, increases in parallel during the last two weeks of gestation. These results, coupled with results obtained from in vivo studies (Sangild et al. 1993, 1997, 2002b), show that the endocytotic capacity of the developing pig intestine reaches its maximum at term or a few days before term. 


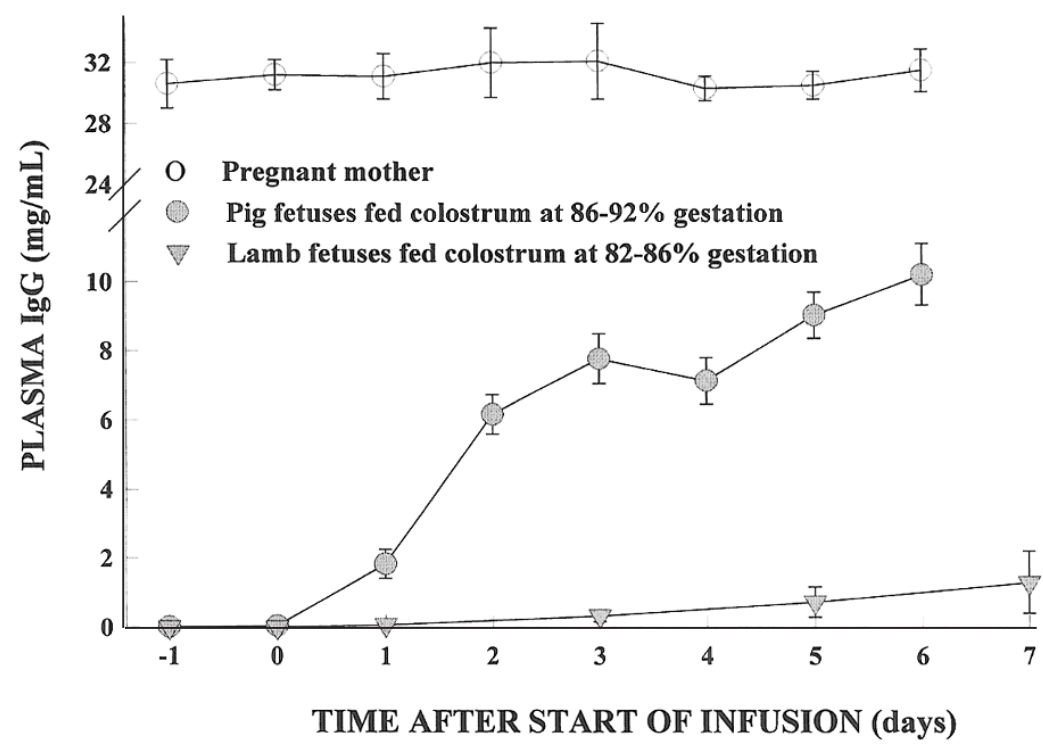

Figure 3. Plasma immunoglobulin $\mathrm{G}(\mathrm{IgG})$ levels (means \pm SEM) in fetal lambs fed ovine colostrum from 82 $86 \%$ gestation (low uptake), and in fetal pigs fed porcine colostrum from $86-92 \%$ gestation (higher uptake). The IgG levels in the colostrum diets, and in the plasma of the pregnant mothers, were similar in the two experiments. Data compiled from studies of Trahair \& Sangild (2000) and Sangild et al. (1999).

\section{Intestinal endocytotic capacity in the fetus}

The results obtained in premature animals have lead us to study in more detail how the fetal intestine responds to infusion of colostrum and how the resulting uptake of immunoglobulins may differ from the situation in newborn animals. Our studies on both pig fetuses (Sangild et al. 1999a) and lamb fetuses (Trahair \& Sangild 2000) show that intestinal macromolecule uptake is present in utero, during the last weeks of gestation, but that it is markedly less in the fetus than in the neonate. Particularly in fetal lambs (studies performed at $82-86 \%$ gestation) was the ability to absorb a series of infused marker molecules (immunoglobulins, albumins) very low, while fetal pigs (studies performed at $86-92 \%$ gestation) showed a somewhat higher uptake capacity (Sangild et al. 1999a). We believe that the small difference in gestational ages is the main reason for a much higher absorptive capacity in fetal pigs, compared with fetal lambs in these studies. A comparison of the IgG profile in the fetal lambs and fetal pigs infused with colostrums in the experiments are shown in Figure 3 together with the approximate $\mathrm{IgG}$ concentrations of the corresponding pregnant mothers. These observations confirm results obtained in vitro (Sangild et al. 2002a) in that the ability to take up and transfer intact proteins from the epithelium into the circulation is a very time-specific process that develops close to term. Thus, the uptake of macromolecules by the newborn farm animal is not merely the result of "intestinal immaturity", but reflects a specific maturational process that shows maximal capacity at birth.

In the studies on pig fetuses (Sangild et al. 1999a), the gradual decline in protein absorp- 


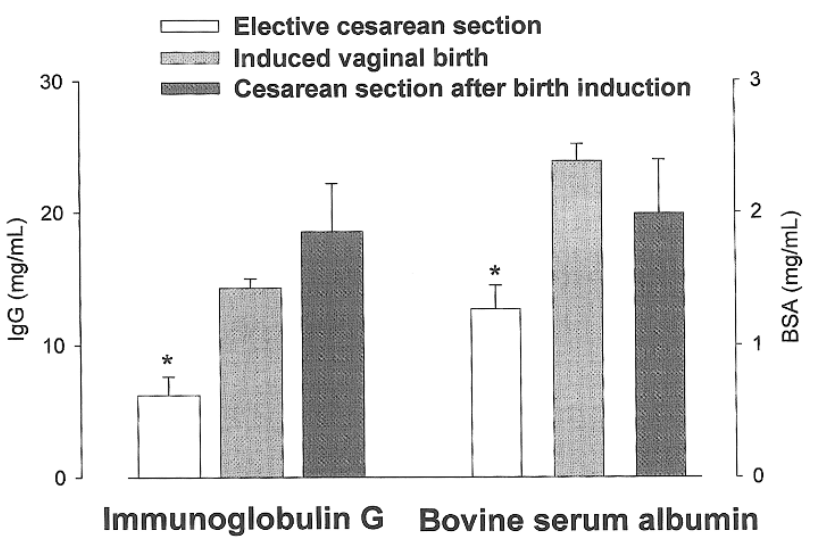

Figure 4. Plasma immnunoglobulin $\mathrm{G}(\mathrm{IgG})$ and bovine serum albumin (BSA) levels (means \pm SEM) in three groups of newborn premature pigs given porcine colostrum + BSA just after birth. Pigs born by elective caesarean section, without prior induction of parturition with a prostaglandin analogue, showed severely reduced capacity to absorp $\operatorname{IgG}$ and BSA from colostrum $(*, \mathrm{P}<0.05)$, compared with premature pigs subjected birth induction (either caesarean- or vaginallydelivered) (Sangild et al., unpublished observations). tive capacity in pigs fed colostrum occurred slower than in newborn pigs, and the intestine retained some protein absorptive capacity even after 3-4 days of exposure to colostrum in utero. The factors responsible for mediating closure in both fetal pigs and newborn pigs are known to be present in the whey fraction of colostrum. The fact that the infused volume of colostrum whey in the fetal pig studies was much less (40 $\mathrm{ml} \mathrm{kg} \mathrm{kg}^{-1}$ ) than that normally taken up by suckling newborn pigs $\left(400 \mathrm{ml} \mathrm{kg}^{-1} \mathrm{~d}^{-1}\right)$, is unlikely to have affected the results, regarding intestinal closure. Volumes as small as $10 \mathrm{ml} \mathrm{kg}$ 1 are known to be effective in inducing closure at the expected time in newborn pigs (Svendsen et al. 1990). The extended pre-closure period in fetuses may be explained by a functional immaturity of the intestine in the weeks before term which prolongs the protein absorptive period. Further, the state of parenteral nutrition in utero (via the placenta) may delay intestinal closure in fetuses similar to the delayed closure observed in parenterally-fed neonatal pigs (Mehrazar et al. 1993), and in newborn pigs and calves fasted for some time after birth (Tyler \& Ramsey 1993, Klobasa et al. 1990). In conclusion, the results on fetuses have substan- tiated the view that the final maturation of the epithelium for macromolecule absorption occurs in close association with the prepartum processes leading to delivery.

\section{Birth by cesarean section}

Cesarean section, as a mode of delivery, can be used for a number of reasons, but is usually performed to protect the mother during labour (dystocia) and to prevent the fetus from suffering excessively from physical and metabolic stress (hypoxia, acidosis) during vaginal birth. When cesarean section is performed during labour ("warm cesarean section"), both the mother and fetus have already been exposed to the physical, metabolic and endocrine changes associated with normal parturition. Such exposure is absent when cesarean section is performed on term or preterm pregnant mothers not in labour. The latter mode of delivery is denoted "elective cesarean section" and is often associated with a decreased survival of the newborn, apparently due to some lack of "birth stress". This is reflected in the significantly lowered levels of plasma cortisol in newborn pigs delivered by elective cesarean section, both preterm and at normal term (Sangild et al. 


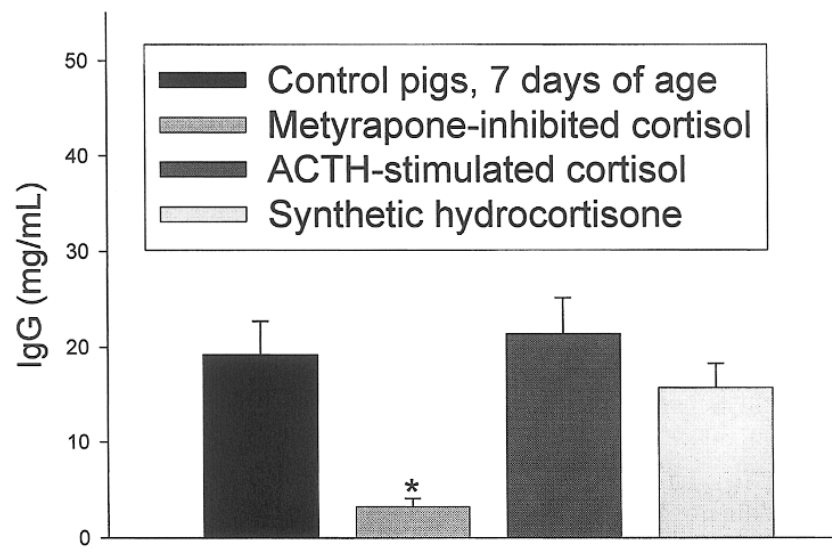

Figure 5. Plasma IgG levels (means \pm SEM) in 7 day old pigs treated with saline (control), metyrapone (a cortisol inhibitor), adrenocorticotropin (ACTH, stimulation of endogenous cortisol secretion) or hydrocortisone acetate (phamacological doses of synthetic cortisol). ${ }^{*}, \mathrm{P}<0.05$ relative to control pigs.

1997). This could be important for the macromolecule uptake capacity since glucocorticoid hormones are known to affect the early maturation of the intestinal epithelium in many species (Henning et al. 1994, Sangild et al. 1995).

The effect of elective cesarean section on the intestinal immunoglobulin uptake capacity has been investigated in some detail in premature pigs and calves. For premature newborns, the initial uptake of IgG is clearly reduced in response to elective cesarean section compared with induced vaginal birth (Jonston \& Oxender 1986, Sangild et al. 1997). The achieved final IgG levels are therefore lowered, although a slightly longer pre-closure period may in part compensate for a reduced initial uptake capacity. In Figure 4 the circulating $\operatorname{IgG}$ and BSA levels are shown for newborn premature pigs (106-108 days gestation) delivered either by elective caesarean section, by caesarean section following prior birth induction ("warm caesarean"), or by induced vaginal birth (Sangild et al. unpublished observations). As reflected in the IgG and BSA levels measured at $9 \mathrm{~h}$ after ingestion of these macromolecules only the elective caesarean group showed reduced uptake capacity. Thus, it appears that the prepartum physiological events, rather than the physi- cal birth process itself, are responsible for the stimulating effects of vaginal birth on intestinal IgG and BSA uptake capacity.

In piglets delivered at full term the initial IgG and BSA uptake capacity is only marginally reduced in response to cesarean section, and coupled with a longer pre-closure period, the resulting IgG levels were actually higher in cesarean-delivered animals than in those born vaginally (Sangild et al. 1997). These results provide some indirect evidence for a stimulating effect of vaginal birth on the initial macromolecule absorptive capacity in the (premature) intestine. Nevertheless, the simultaneous effect on the timing of intestinal closure makes it difficult to ascertain whether the final IgG levels will be elevated or lowered in cesareandelivered animals. The different responses at different fetal ages at delivery may be due to developmental changes in the intestinal responsiveness to glucocorticoids. It remains unclear however, whether elective cesarean section, via the lack of cortisol, influences the intestinal immunoglobulin uptake capacity in the large farm animals. Therefore a more detailed look at the effects of cortisol (the main glucocorticoid in farm animals) on the developing intestinal epithelium is warranted. 


\section{The role of cortisol}

Studies in rats and mice have shown that glucocorticoids advance the timing of intestinal closure occurring at 2-3 weeks of age (Daniels et al. 1973b, Moog 1979). The mechanisms whereby this takes place include an increased cell replacement in the intestinal mucosa (Trahair \& Robinson 1989, Henning et al. 1994). Consistent with this, Bate et al. (1991) observed histological changes and a decreased intestinal uptake of bovine immunoglobulin $\mathrm{G}$ in newborn piglets from sows with elevated cortisol levels in late gestation. In this study it was not known however, whether fetal glucocorticoid levels were affected. Several observations suggest that the cellular mechanisms of closure and the role of cortisol in intestinal closure differ between rodents and the large farm animals. Firstly, the limiting factor for macromolecule uptake in pigs is the transmission of these molecules into the blood stream (lasting 12-36 hours), and not the uptake into the vacuolated cells of the intestinal mucosa (lasting about 3 weeks) (Clarke \& Hardy 1971, Smith \& Jarvis 1978). Secondly, cell migration rate does not normally change during the first days of postnatal life in pigs (Smith \& Jarvis 1978) or after glucocorticoid treatment (James et al. 1987a). Thirdly, neonatal cesarean-delivered piglets and lambs show severely depressed immunoglobulin $\mathrm{G}$ uptake into plasma after metyrapone treatment (inhibition of cortisol synthesis) (Patt \& Eberhart 1976, Hough et al. 1990, Sangild et al. 1993). Metyrapone treatment of spontaneously delivered newborn calves also decreases immunoglobulin absorption in the immediate postnatal period (Johnston \& Oxender 1979), but the depression is less severe than that observed in the above studies on pigs and lambs. Hence, the literature indicates that in the farm animal species cortisol stimulates (rather than inhibits) macromolecule transport across the newborn small intestine. In Figure 5, we have shown the effects of variable cortisol levels on the IgG uptake capacity in newborn cesarean-delivered pigs (data in part from from Sangild et al. 1993).

In cesarean-delivered pigs, metyrapone treatment seems to be associated with a decreased absorptive capacity of the intestinal epithelium (Patt \& Eberhart 1976, Sangild et al. 1993), while the effect in cesarean-delivered lambs is due to both a reduction in the absorptive capacity and in the time available for absorption (Hough et al. 1990). The effect of depressed cortisol may depend on the time of delivery. In premature lambs, there are effects both on the initial rate of protein uptake and on the timing of intestinal closure. In term lambs, the effect on closure is dominant (Hough et al. 1990). It is possible that the effects of cortisol on the endocytotic capacity of intestinal cells disappear shortly before term when intestinal function is relatively mature, partly mediated by the normal surge in plasma cortisol. The effect may also disappear earlier in the lamb than in the pig as the prenatal rise in cortisol occurs more gradually in the lamb compared with the pig (Silver et al. 1983, Fowden et al. 1996).

Treatment of newborn pigs (Patt \& Eberhart 1976, Sangild et al. 1993), calves (Johnston \& Oxender 1979, Stott 1980) or foals (Carrick et al. 1987) with ACTH does not increase immunoglobulin absorption in these species. A glucocorticoid related maturation of the absorptive capacity may have occurred already before birth in these species and prevented an additional increase in glucocorticoid exposure from having any effect. This hypothesis is consistent with the fact that ACTH treatment induces a slight increase in the immunoglobulin absorptive capacity in premature cesarean-delivered lambs ( $92 \%$ gestation) whereas there is no effect when lambs are delivered closer to term (95\% gestation) (Hough et al. 1990). In preterm lambs, a single peak in plasma cortisol 
(following an ACTH injection) has the same stimulating effect as continuous treatment with cortisol acetate (Hough et al. 1990). This suggests that immature intestinal enterocytes only require a short-term exposure to high glucocorticoid levels to express their full endocytotic potential.

Treatment of pregnant cows with a long-acting glucocorticoid does not prevent the reduction in immunoglobulin absorption in calves caused by premature birth (Bailey et al. 1973, Husband et al. 1973). This can be explained by an immaturity of the intestine as immunoglobulin absorption is normal in calves following glucocorticoid induced birth close to normal term (Muller et al. 1975). Although premature calves born after glucocorticoid induction may absorb less immunoglobulin than normal newborn calves, they do absorb significantly higher amounts than premature calves delivered by elective cesarean section (Johnston \& Stewart 1986). The effects of glucocorticoids on intact protein absorption thus depend on the maturity of the intestinal cells at treatment, and the period of maximal glucocorticoid responsiveness before and after birth varies between the pig, lamb and calf.

\section{Birth difficulties}

Dystocia causes a reduction in neonatal viability in farm animals (Nix et al. 1998, Bellows et al. 2000) and in some studies, the increased morbidity has been associated with a reduced IgG absorption (Burton et al. 1989, Perino et al. 1995). In particular, studies in calves have shown that dystocia-induced respiratory acidosis and hypercapnia are followed by decreased absorption of IgG (Besser et al. 1990). This inhibition of uptake may occur both at the level of initial endocytotic capacity in intestinal cells and by an earlier induction of intestinal closure. Nevertheless, it remains unclear whether dystocia alone can influence IgG absorption (Burton et al. 1989) and to which extent this is directly or indirectly related to postnatal acidosis and hypercapnia (Boyd 1989). In this context, it is important also to consider the circulating cortisol levels which might influence the absorptive capacity (see above). Thus, elevated cortisol levels in response to excessive physical and metabolic stress around the time of birth could mature the immature enterocytes and cause enhanced (rather than impaired) absorption. The circulating cortisol level has been found to be elevated in dystocial and acidotic neonatal calves in some studies (Hoyer et al. 1990) while in others the level has been lowered (Stott \& Reinhard 1978). In a recent study (Jacobsen et al. 2002), we found no correlation between the cortisol levels and the extent of birth difficulties for newborn calves, but cortisol levels during the first $2 \mathrm{~h}$ after birth correlated negatively with peak plasma IgG concentration. Hence, there is evidence for both positive and negative correlations between cortisol and IgG levels in newborn animals.

The conflicting results, regarding the effects of dystocia and plasma cortisol on macromolecule absorption, may be explained by the fact that the maturational effects of cortisol on the intestinal epithelium are highly developmentally dependent (see earlier). In addition, there may be effects that are counteracting each other. Positive effects of "birth stress" on IgG absorption may be present mainly in premature animals having an immature epithelium at birth, while in term animals, the effects of birth stress are more likely to inhibit immunoglobulin uptake. Such effects of excessive birth stress could be mediated directly or indirectly via the dystocia-induced abnormal blood gas values (hypoxia, hypercapnia, acidosis), metabolite concentrations (low glucose, high lactate) or endocrine status (elevated cortisol, adrenalin). At present however, the available literature provides no conclusive evidence for these hypothe- 


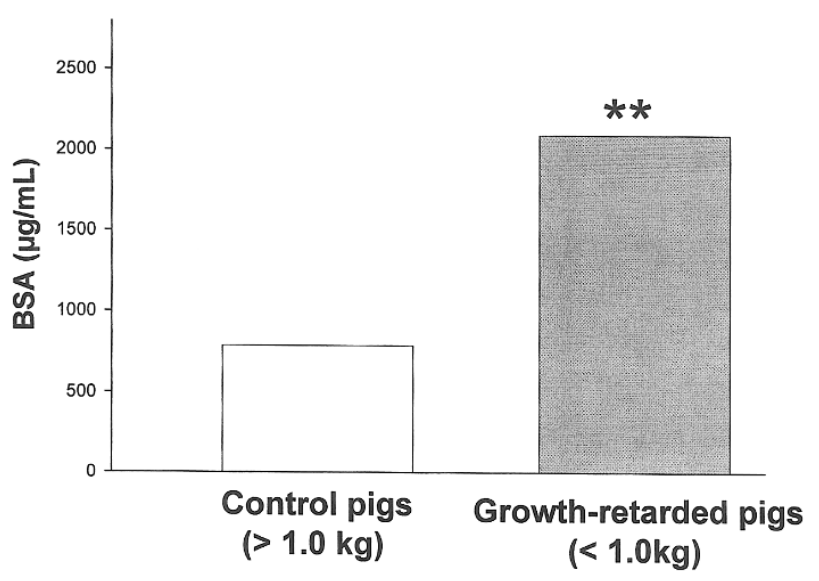

Figure 6. Plasma bovine serum albumin (BSA) levels (means " SEM) in newborn control and growth-retarded pigs. **, $\mathrm{P}<0.01$ relative to control pigs. The graph has been drawn based on data by Svendsen et al. (1990). ses and more research is needed to elucidate the effects of birth stress on the ability of the small intestine to absorb immunoglobulins. It remains however, that the reduction in IgG uptake, documented in some studies on dystocial newborn animals, is quantitatively small. This suggests that the process of birth per se does not exert a major influence on the timing and the extent of endocytosis in the newborn small intestine.

\section{Growth retarded newborn animals}

Intra-uterine growth retardation is a common problem observed among farm animals, particularly in species with large litters (e.g. pigs). The different factors that contribute to a low birth weight at term include genetic predisposition, poor maternal nutrition and fetal/maternal infection. Such influences may cause a sub-optimal supply of nutrients and oxygen to the developing fetus across the placental vascular beds. Due to the multi-factional etiology of the low birth weight syndrome, its effects on intestinal immunoglobulin absorption vary depending on the exact reason for fetal growth retardation.

The increased mortality most often observed for weak, low birth weight pigs, calves and lambs suggests that the intestinal capacity to absorb macromolecules in these newborns may be compromised. In fact, the available evidence suggests that the opposite is the case. In our own studies (Sangild et al. 1996, 1997; 1999, Jensen et al. 2001), we have never observed any consistent relation between body weight and immunoglobulin absorption. More importantly, the results of Svendsen et al. (1990) document that growth retarded newborn piglets $(<1.0 \mathrm{~kg}$ body weight) actually have a greater capacity to absorb certain large molecules than their normal birth weight counterparts. In these studies, the difference in uptake between low birth weight and normal birth weight pigs was most pronounced when bovine serum albumin (BSA) was used as a marker molecule, and not evident when dextran was used. Since the absorptive capacity for BSA is closely related to that of immunoglobulins (Weström et al. 1985, Jensen et al. 2001), it is conceivable that the low birth weight piglets will also show a greater immunoglobulin uptake capacity. Hence, the authors conclude that pigs which may be classified as underprivileged at birth, in part due to low birth weight, have a greater capacity to ob- 
tain the protective immunoglobulins from their mother's colostrum, provided that they get access to colostrum of high quality. Some results which have been compiled from the studies of Svendsen et al. (1990) are shown in Figure 6. These results underscore the need to provide apparently weak and low birth weight neonates with adequate immunoglobulins, either from their own mother or via artificial feeding. It remains important however, to carefully consider the nature of the colostrum substitute used. As discussed previously, the nature of the feed has a profound influence on the ability of the intestinal cells to absorb immunoglobulins.

It is not clear why growth-retarded newborn animals have an enhanced capacity to absorb macromolecules. Nevertheless, there are some general characteristics of fetal growth retardation that may exert a direct effect on the maturation of the small intestine, and its ability to absorb immunoglobulins. In particular, it appears that many fetuses born at term, but with low birth weight, have experienced prolonged hypoxic or nutritional stress in utero leading to a premature increase in adrenal secretion of cortisol which in turn induces premature maturation in all gut functions that are stimulated by cortisol (Trahair \& Sangild, 1997). Hence, elevated cortisol levels in response to intra-uterine stress may explain the enhanced macromolecule uptake capacity in low birth weight animals. Stillborn pigs, and low birth weight pigs born alive, show histological characteristics in their adrenal glands indicative of prenatal exposure to stress and elevated cortisol levels (Svendsen 1982, Björklund et al. 1987). Correspondingly, elevated levels of corticotropin releasing hormone $(\mathrm{CRH})$ and adrenocorticotropin (ACTH) have been detected in human fetuses born after intra-uterine growth retardation (Goland et al. 1993).

Although cortisol undoubtedly plays a role for the maturation of the small intestine, including its ability to absorb large molecules, the effects are highly age- and diet-dependent. In a recent study on fetal pigs (Sangild et al. 2002a), prevention of fetal swallowing by experimental gut obstruction was associated with both fetal body growth retardation and significantly elevated cortisol levels. Nevertheless, the ability of the small intestine to absorb large molecules by endocytosis, as measured in vitro, was not affected. Thus, the functional links among fetal growth retardation, plasma cortisol, and intestinal macromolecule absorptive capacity, remain obscure.

\section{In vitro embryo production}

Decreased viability and increased perinatal mortality is one of the drawbacks reported from offspring produced after transfer of in vitro produced (IVP) embryos in cattle reproduction. Larger calves at birth and a higher incidence of dystocia have been reported (Kruip \& den Daas 1997, Hasler 2000, Wagtendonk-de Leeuw et al. 2000). Factors influencing the viability of the newborn calf include maturation prior to birth, the stress of parturition and passive immunisation of the calf from colostrum (Penny et al. 1995). All of these factors have also been speculated to contribute to the lower viability of calves derived from IVP embryos but as yet, there are no clear evidence for physiological changes that can be directly linked to impaired survival. The results of IVP embryo production are highly variable among different laboratories, and differences in techniques used to perform in vitro embryo production complicate comparisons among studies. It remains, however, that calves produced after embryo cloning suffer more from abnormalities than calves produced after more conventional in vitro fertilization techniques, using only limited manipulation of the developing oocyte or embryo (Smith et al. 2000).

In studies on different groups of IVP calves, $\mathrm{Ja}$ - 


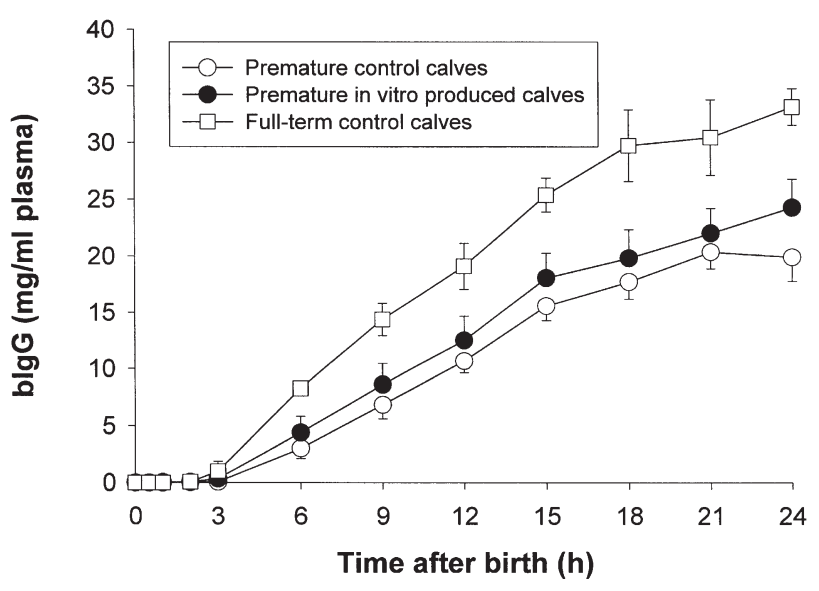

Figure 7. The concentration of bovine $\operatorname{IgG}$ in plasma (means \pm SEM) in groups of premature calves (caesarean delivery at $90 \%$ gestation, control calves or calves subjected to in vitro embryo production), and in calves delivered at normal term. The results suggest that premature delivery, but not the mode of embryo production, reduces the ability of the developing small intestine to absorp macromolecules (Sangild et al., unpublished observations). cobsen et al. (2002) found a lowered plasma $\mathrm{IgG}$ level in calves produced after a certain IVP method (co-culture of embryos without serum in the culture medium), but several lines of evidence suggest that the effect of IVP was small. Firstly, the serum IgG concentration was clearly above those considered to be necessary for passive immunisation and secondly, there was no difference between different IVP groups in the absorption efficiency of a non-IgG macromolecule, porcine serum albumin (PSA). Thirdly, the differences in mean IgG and PSA levels in plasma among different embryo treatments were quantitatively no greater than the differences associated with the variable degrees of birth dystocia as indicated by blood $\mathrm{pH}$ at birth. In fact, a major part of the variation in circulating IgG levels in newborn calves could be explained by the variable degree of dystocia rather than by the method of embryo production.

Blood chemistry values, and plasma cortisol, have generally shown little relation to methods of embryo production in both full-term spontaneously-delivered IVP calves (Jacobsen et al. 2000) and premature, cesarean-delivered IVP calves (Sangild et al. 2000). In term IVP calves, the absorption of IgG and other macro- molecules is not notably affected relative to control calves (Jacobsen et al. 2002) and also in some recent studies on premature calves, was the method of embryo production less important than gestational age at delivery (premature or term, Sangild et al., unpublished observations). Some of these results have been presented in Figure 7, and they support and extend the results obtained earlier by Bailey et al. (1998) regarding minimal effects of in vitro embryo production on intestinal IgG uptake capacity. Hence, we conclude that a decreased ability of IVP calves to acquire passive immunity from cow's colostrum is unlikely to contribute to the reported increased disease susceptibility of newborn IVP calves.

\section{Conclusion}

In the large farm animal species (horse, cattle, sheep, pig, goat), the newborn animals are normally born without systemic immunity in the form of immunoglobulins and passive transfer of maternal immunoglobulins from the first milk (colostrum) is required until the immune system has been fully developed. The degree of humoral immunological protection depends on the amount and the time of colostrum uptake, the colostral immunoglobulin quality and con- 
centration, and the intestinal capacity to absorb immunoglobulins. Relatively little is known about the food and animal factors that influence the intestinal endocytotic capacity during the first 1-2 days after birth and the present review have described a series of factors that modulate this capacity in newborn animals. Firstly, the food in which the immunoglobulins are dissolved has a pronounced influence on the intestinal endocytotic capacity, and uptake is more efficient with colostrum from the same species than with a colostrum substitute. Secondly, an adequate maturation of the intestinal epithelium is crucial for an efficient intestinal transfer of large molecules. The functional maturation of the intestinal epithelium occurs very rapidly during the last weeks before term and therefore premature birth is associated with impaired immunoglobulin absorption. Other factors, including a lowered circulating level of cortisol, contributes to low immunoglobulin absorption in premature animals, particularly if the route of delivery is cesarean section. When birth occurs at full term the effects of mode of birth, and birth difficulties, on intestinal immunoglobulin absorption are less consistent. Correspondingly, the possible functional links among intestinal endocytotic capacity, plasma cortisol and blood chemistry (e.g. blood pH, oxygen, lactate, glucose) remain to a large extent unresolved. Finally, the literature indicates that the lowered neonatal survival associated with intra-uterine growth retardation (low birth weight) and in vitro production of embryos is not linked to a lowered capacity of the intestinal epithelium to absorb immunoglobulins. Hence, the nature of the feed (colostrum, milk, milk-replacer) and the stage of intestinal maturation appear to be the two most crucial factors affecting the epithelial capacity to absorb immunoglobulins in newborn farm animals. This information may help to improve the clinical care of 'compromised' newborns.

\section{Acknowledgements}

Many investigators involved in parts of the work carried out by the author are gratefully acknowledged. These include Mette Schmidt, Helene Jacobsen, Torben Greve, Jan Elnif, Jeff Trahair, Abigail Fowden, Marian Silver and Björn Weström. The author's own work has been sponsored by the Danish Agricultural and Veterinary Research Council and the NOVO Foundation.

\section{References}

Bailey M, Plunkett FJ, Rothkotter HJ, Vega-Lopez $M A$, Haverson K, Stokes CR: Regulation of mucosal immune responses in effector sites. Proc. Nutr. Soc. 2001, 60, 427-435.

Bailey LF, McLennan, MW, McLean DM, Hartford $P R$, Munro GL: The use of dexamethasone trimethylacetate to advance parturition in dairy cows. Austr. Vet. J. 1973, 49, 567-573.

Bailey TL, Whittier WD, Murphy JM, Schurig GG, Riva AL, Swecker WS, Pelzer KD, Bass RT, Caudell D, Eyestone $W$ : Serum immunoglobulin type $\mathrm{G}$ concentrations in calves produced by IVF and delivered by elective cesarean section. Theriogenology 1998, 50, 853-860.

Baintner $K$ : Intestinal Absorption of Macromolecules and Immune Transmission from Mother to Young. CRC Press, 1986, Boca Raton, Florida, $240 \mathrm{pp}$

Bate LA, Ireland W, Connell BJ, Grimmelt B: Development of the small intestine of piglets in response to prenatal elevation of glucocorticoids. Histol. Histopathol. 1991, 6, 207-216.

Bellows RA, Lammoglia MA: Effects of severity of dystocia on cold tolerance and serum concentrations of glucose and cortisol in neonatal beef calves. Theriogenology 2000, 53, 803-813.

Besser TE, Szenci O, Gay CC: Decreased colostral immunoglobulin absorption in calves with postnatal respiratory acidosis. J. Am. Vet. Med. Assoc. 1990, 196, 1239-1243.

Bjorklund NE, Svendsen J, Svendsen LS: Histomorphological studies of the perinatal pig: comparison of five mortality groups with unaffected pigs.Acta Vet Scand 1987, 28, 105-116.

Blum JW, Baumrucker CR: Colostral and milk insulin-like growth factors and related substances: mammary gland and neonatal (intestinal and systemic) targets. Domest. Anim. Endocrinol. 2002, 23, 101-110.

Boutinaud M, Jammes $H$ : Potential uses of milk ep- 
ithelial cells: a review. Reprod. Nutr. Dev. 2002, 42, 133-147.

Boyd JW: Relationships between acid-base balance, serum composition and colostrumabsorption in newborn calves. Br. Vet. J. 1989, 145, 249-256.

Burrin DG, Davis TA, Ebner S, Schoknecht PA, Fiorotto ML, Reeds PJ, McAvoy, S: Nutrient-independent and nutrient-dependent factors stimulate protein synthesis in colostrum-fed newborn pigs. Pediatr. Res. 1995, 37, 593-599.

Burton JL, Kennedy BW, Burnside EB, Wilkie BN, Burton JH: Variation in serum concentrations of immunoglobulins G, A, and M in Canadian Holstein-Friesian calves. J. Dairy Sci. 1989, 72, 135149.

Butler JE: Immunologic aspects of breast feeding, antiinfectious activity of breast milk. Semin. Perinatol. 1979, 3, 255-270.

Butler JE: Immunoglobulin diversity, B-cell and antibody repertoire development in large farm animals. Rev. Sci. Tech. 1998, 17, 43-70.

Carlsson LCT, Weström BR, Karlsson BW: Intestinal absorption of proteins by the neonatal piglet fed on sow's colostrum with either natural or experimentally eliminated trypsin-inhibiting activity. Biol. Neonate 1980, 38, 309-320.

Carrick JB, Pollitt CC, Thompson HL, Inglis S, Galligan JP: Failure of the administration of ACTH to affect the absorption of colostral immunoglobulin in neonatal foals. Equine. Vet. J. 1987, 19, 545-547.

Clarke RM, Hardy RN: Structural changes in the small intestine associated with the uptake of polyvinyl pyrrolidone by the young ferret, rabbit, guinea-pig, cat and chicken. J. Physiol. 1970, 209, 669-687

Clarke RM, Hardy RN: Histological changes in the small intestine of the young pig and their relation to macromolecular uptake. J. Anat. 1971, 108, 63-77

Coleman MA, Keelan JA, McCowan LM, Townend $K M$, Mitchell $M D$ : Predicting preterm delivery: comparison of cervicovaginal interleukin (IL)1 beta, IL- 6 and IL-8 with fetal fibronectin and cervical dilatation. Eur. J. Obstet. Gynecol. Reprod. Biol. 2001, 95, 154-158.

Daniels VG, Hardy RN, Malinowska KW: The effect of adrenalectomy or pharmacological inhibition of adrenocortical function on macromolecule uptake by the new-born rat intestine. J. Physiol. 1973a, 229, 697-707.

Daniels VG, Hardy RN, Malinowska KW, Nathanielsz
$P W$ : The influence of exogenous steroids on macromolecule uptake by the small intestine of the new-born rat. J. Physiol. 1973b, 229, 681695.

Drew MD, Owen BD: The provision of passive immunity to colostrum-deprived piglets by bovine or porcine serum immunoglobulins. Can. J. Anim. Sci. 1988, 68, 1277-1284.

Fowden AL, Szemere J, Hughes P, Gilmour RS, Forhead AJ: The effects of cortisol on the growth rate of the sheep fetus during late gestation. J. Endocrinol. 1996, 151, 97-105.

Frenyo, VL: Studies on the absorption of homologous and heterologous IgG in artificially-reared newborn pigs. Vet. Res. Commun. 1987, 11, 23-30

Goland RS, Jozak S, Warren WB, Conwell IM, Tark RI, Tropper PJ: Elevated levels of umbilical cord plasma corticotropin-releasing hormone in growth-retarded fetuses. J. Clin. Endocrinol. Metab. 1993, 77, 1174-1179.

Gomez GG, Phillips O, Goforth RA: Effect of immunoglobulin source on survival, growth and hematological and immunological variables in pigs. J. Anim. Sci. 1998, 76, 1-7.

Hasler JF: In-vitro production of cattle embryos: problems with pregnancies and parturition. Hum. Reprod. 2000, 15, 47-58

Henning SJ, Rubin DC, Shulman RJ: Ontogeny of the intestinal mucosa. In: Physiology of the Gastrointestinal Tract, 3rd ed. (Johnson, L.R. ed.), 1994, pp. 571-610. Raven Press, New York.

Hough RL, McCarthy FD, Thatcher CD, Kent HD, Eversole $D E$ : Influence of glucocorticoid on macromolecular absorption and passive immunity in neonatal lambs. J. Anim. Sci. 1990, 68, 2459-2464.

Hoyer C, Grunert E, Jochle W: Plasma glucocorticoid concentrations in calves as an indicator of stress during parturition. Am. J. Vet. Res. 1990, 51, 1882-1884.

Husband AJ, Brandon MR, Lascelles AK: The effect of corticosteroid on absorption and endogenous production of immunoglobulins in calves. Austr. J. Exp. Biol. Med. Sci. 1973, 51, 707-710.

Israel EJ, Simister N, Freiberg E, Caplan A, Walker WA: Immunoglobulin $\mathrm{G}$ binding sites on the human foetal intestine: a possible mechanism for the passive transfer of immunity from mother to infant. Immunology 1993, 79, 77-81.

Jackson JR, Hurley WL, Easter RA, Jensen AH, Odle $J$ : Effects of induced or delayed parturition and supplemental dietary fat on colostrum and milk 
composition in sows. J. Anim. Sci. 1995, 73, 1906-1913.

Jacobsen H, Sangild PT, Schmidt M, Holm P, Greve $T$, Callesen $H$ : Macromolecule absorption and cortisol secretion in newborn calves derived from in vitro produced embryos. Anim. Reprod. Sci. 2002, 70, 1-11.

Jacobsen H, Schmidt M, Holm P, Sangild PT, Greve $T$, Callesen $H$ : Ease of calving, blood chemistry, insulin and bovine growth hormone of newborn calves derived from embryos produced in vitro in culture systems with serum and co-culture or with PVA. Theriogenology 2000, 54, 147-158.

Jacobsson I, Lindberg T, Lothe L, Axelsson I, Benediktsson B: Human alpha-lactalbumin as a marker of macromolecular absorption. Gut 1986, 27, 1029-1034

James PS, Smith MW, Tivey DR, Wilson TJG: Dexamethasone selectively increases sodium-dependent alanine transport across neonatal piglet intestine. J. Physiol. 1987, 393, 569-582.

Jensen AR, Elnif J, Burrin DG, Sangild PT: Development of intestinal immunoglobulin absorption and enzyme activities in neonatal pigs is diet-dependent. J. Nutr. 2001, 132 (in press).

Jiang R, Chang X, Stoll B, Ellis KJ, Shypailo RJ, Weaver E, Campbell J, Burrin DG: Dietary plasma protein is used more efficiently than extruded soy protein for lean tissue growth in earlyweaned pigs. J. Nutr. 2000, 130, 2016-2019.

Johnston NE, Stewart JA: The effect of glucocorticoids and prematurity on absorption of colostral immunoglobulin in the calf. Aust. Vet. J. 1986, 63, 191-192.

Johnston NE, Oxender WD: Effect of altered serum glucocorticoid concentrations on the ability of the newborn calf to absorb colostral immunoglobulin. Am. J. Vet. Res. 1979, 40, 32-34.

Kim YB: Developmental immunity in the piglet. Birth Defects 1975, 11, 549-557.

Klobasa F, Butler JE: Absolute and relative concentrations of immunoglobulins G, M, and A, and albumin in the lacteal secretion of sows of different lactation numbers. Am. J. Vet. Res. 1987, 48, 176-182.

Klobasa F, Greimann H, Kallweit E: The "waiting period" for follow-up administration of bovine colostrum to newborn lambs. Berl. Munch. Tierarztl. Wochenschr. 1994, 107, 334-339.

Klobasa F, Habe F, Werhahn E: The absorption of colostral immunoglobulins in newborn piglets. I. Effect of time from birth to the first feeding. Berl.
Munch. Tierarztl. Wochenschr. 1990, 103, 335340.

Klobasa F, Habe F, Werhahn E: The absorption of colostral immunoglobulins in newborn piglets. II. Effect of water or glucose solutions on the permeability of the newborn intestine. Berl. Munch. Tierarztl. Wochenschr. 1991, 104, 37-41.

Kruip, TA, den Daas, JH: In vitro produced and cloned embryos: Effects on pregnancy, parturition and offspring. Theriogenology 1997, 47, 4352.

Martin $M G$, Wu SV, Walsh JH: Ontogenetic development and distribution of antibody transport and Fc receptor mRNA expression in rat intestine. Dig. Dis. Sci. 1997, 42, 1062-1069.

McCallum IM, Elliot JI, Owen BD: Survival of colostrum-deprived neonatal piglets fed gammaglobulins. Can. J. Anim. Sci. 1977, 57, 151-158.

Mehrazar K, Gilman-Sachs A, Kim YB: Intestinal absorption of immunologically intact macromolecules in germfree colostrum-deprived piglets maintained on total parenteral nutrition. J. Parenter. Enteral. Nutr. 1993, 17, 8-15.

$\operatorname{Moog} F$ : Endocrine influences on the functional differentiation of the small intestine. J. Anim. Sci. 1979, 49, 239-249.

Muller LD, Beardsley GL, Ellis RP, Reed DE, Owens $M J$ : Calf response to the initiation of parturition in dairy cows with dexamethasone or dexamethasone with estradiol benzoate. J. Anim. Sci. 1975, 41, 1711-1716.

Nix JM, Spitzer JC, Grimes LW, Burns GL, Plyler BB: A retrospective analysis of factors contributing to calf mortality and dystocia in beef cattle. Theriogenology 1998, 49, 1515-1523.

Pakkanen R, Aalto J: Growth factors and antimicrobial factors of bovine colostrum. Int. Dairy J. 1997, 7, 285-297.

Patt JAJ, Eberhart RJ: Effects of metyrapone and ACTH on intestinal absorption of immunoreactive bovine IgG in cesarean-derived pigs. Am. J. Vet. Res. 1976, 37, 1409-1413.

Penny CD, Lowman BG, Scott NA, Scott PR, Voelkel $S$, Davies DA: Management aspects of induced twinning in beef suckler cows using in vitro fertilised embryos. Vet. Rec. 1995, 136, 506-510.

Perino LJ, Wittum TE, Ross GS: Effects of various risk factors on plasma protein and serum immunoglobulin concentrations of calves at postpartum hours 10 and 24. Am. J. Vet. Res. 1995, 56, 1144-1148.

Playford RJ, MacDonald CE, Calnan DP, Floyd DN, 
Podas T, Johnson W, Wicks AC, Bashir O, Marchbank T: Co-administration of the health food supplement, bovine colostrum, reduces the acute non-steroidal anti-inflammatory drug-induced increase in intestinal permeability. Clin. Sci. 2001, 100, 627-633.

Roberton DM, Paganelli R, Dinwiddie R, Levinsky $R J$ : Milk antigen absorption in the preterm and term neonate. Arch. Dis. Child. 1982, 57, 369372.

Sangild PT, Diernces L, Christiansen IJ, Skadhauge $E$ : Intestinal transport of sodium, glucose and immunoglobulin in neonatal pigs. Effect of glucocorticoids. Exp Physiol 1993, 78, 485-497.

Sangild PT, Fowden AL, Sjöström H, Norén O\& Silver $M$ : The prenatal development and glucocorticoid control of brush-border hydrolases in the pig small intestine. Pediatr. Res. 1995, 37, 207-212.

Sangild PT, Holtug K, Diernoes L, Schmidt M, Skadhauge $E$ : Birth and prematurity influence intestinal function in the newborn pig. Comp Biochem Physiol 1997, 118A, 359-362.

Sangild PT, Jacobsen H, Schmidt M, Fowden AL, Avery B, Greve T: IgG and cortisol levels in newborn premature IVP calves. Theriogenology $1999 b, 51,331$.

Sangild PT, Petersen YM, Schmidt M, Elnif J, Petersen TK, Buddington RK, Michaelsen $K F$, Greisen $G \&$ Burrin DG: Preterm birth affects the gastrointestinal responses to parenteral and enteral nutrition in the newborn pig. Journal of Nutrition 132, 2002b, 2673-2681.

Sangild PT, Schmidt $M$, Elnif J, Björnvad CR, Weström BR, Buddington RK: Prenatal development of gastrointestinal function in the pig and the effects of fetal gut obstruction. Pediatr. Res. 2002a, 52, 416-424.

Sangild PT, Schmidt M, Jacobsen H, Fowden AL, Forhead A, Avery B, Greve T: Blood chemistry, nutrient uptake and organ weights of fetal and newborn calves derived from in vitro produced embryos. Biol. Reprod. 2000, 62, 1495-1504.

Sangild PT, Silver M, Schmidt M, Fowden AL: The perinatal pig in pediatric gastroenterology In: Advances in Swine in Biomedical Research (Tumbleson, ME, Schnook, L, eds.), 1996, pp. 745-756. Plenum press, New York.

Sangild PT, Trahair JF, Loftager MK, Fowden AL: Intestinal macromolecule absorption in the fetal pig after infusion of colostrum in utero. Pediatr. Res. 1999a, 45, 595-602.

Schlimme E, Martin D, Meisel H: Nucleosides and nucleotides: natural bioactive substances in milk and colostrum. Br. J. Nutr. 2000, 84, Suppl 1, S59-S68.

Silver M, Comline RS, Fowden AL: Fetal and maternal endocrine changes during the induction of parturition with the PGF analogue, cloprostenol, in chronically catheterized sows and fetuses. J. Dev. Physiol. 1983, 5, 307-321.

Sinkora M, Sun J, Sinkorova J, Christenson RK, Ford $S P$, Butler JE: Antibody repertoire development in fetal and neonatal piglets. VI. B cell lymphogenesis occurs at multiple sites with differences in the frequency of in-frame rearrangements. J. Immunol. 2003, 170, 1781-1788.

Smith MW, Jarvis LG: Growth and cell replacement in the new-born pig intestine. Proc. R. Soc. (London) 1978, 203, 69-89.

Smith LC, Bordignon V, Babkine M, Fecteau $G$, Keefer $C$ : Benefits and problems with cloning animals. Can. Vet. J. 2000, 41, 919-924.

Staley TE, Bush LJ: Receptor mechanisms of the neonatal intestine and their relationship to immunoglobulins absorption and diseases. J. Dairy Sci. 1985, 68, 184-205.

Stott GH: Immunoglobulin absorption in calf neonates with special considerations of stress. J. Dairy. Sci. 1980, 63, 681-688.

Stott GH, Reinhard EJ: Adrenal function and passive immunity in the dystocial calf. J. Dairy Sci. 1978, 61, 1457-1461.

Svendsen LS: Organ weights of the newborn pig. Characterization and comparison of pigs dying within 48 hours of birth with those of unaffected, growing pigs: stillborn intra partum pigs, weak pigs, splayleg pigs, splayleg and weak (splayweak) pigs, and traumatized pigs Acta Vet. Scand. Suppl. 1982, 78, 1-205.

Svendsen LS, Weström BR, Svendsen J, Olsson AC, Karlsson $B W$ : Intestinal macromolecular transmission in underpriviliged and unaffected newborn pigs: implication for survival of underprivileged pigs. Res.Vet. Sci. 1990, 48, 184-189

Trahair JF, Robinson PM: Enterocyte ultrastructure and uptake of immunoglobulins in the small intestine of the neonatal lamb. J. Anat. 1989, 166, 103-111.

Trahair JF, Sangild PT: Systemic and luminal influences on the perinatal development of the gut. Equine Vet. J. Suppl. 1997, 24, 40-50.

Trahair JF, Sangild PT: Fetal organ growth in response to infusion of amniotic fluid, colostrum, milk, or gastrin-releasing peptide; a study in fetal 
sheep. Reprod. Fert. Dev. 2000, 12, 87-95.

Tyler H, Ramsey H: Effect of insulin-induced hypoglycemia on cessation of macromolecular transport in the neonatal calf. J. Dairy Sci. 1993, 76, 2736-2741.

Varley MA: Neonatal survival: an overview. Br. Soc. Anim. Prod., Occ. Publ. 1992, 15, 1-7. Wagtendonk-de Leeuw AM, Mullaart E, de Roos AP, Merton JS, den Daas JH, Kemp B, de Ruigh L: Effects of different reproduction techniques: AI MOET or IVP, on health and welfare of bovine offspring. Theriogenology 2000, 53, 575-597.

Weaver DM, Tyler JW, VanMetre DC, Hostetler DE, Barrington GM: Passive transfer of colostral immunoglobulins in calves. J. Vet. Intern. Med. 2000, 14, 569-577.

Weaver LT, Walker WA: Uptake of macromolecules in the neonate. In: Lebenthal E (ed.) Human Gastrointestinal Development. Raven Press, New York, 1989, pp 731-748.

Weström BR, Ohlsson BG, Svendsen J, Tagesson C, Karlsson $B W$ : Intestinal transmission of macromolecules (BSA and FITC-Dextran) in the neonatal pig: Enhancing effect of colostrum, proteins and proteinase inhibitors. Biol. Neonate 1985, 47, 359-366.

Weström BR, Svendsen J, Ohlsson BG, Tagesson C, Karlsson $B W$ : Intestinal transmission of macromolecules (BSA and FITC-labelled dextrans) in the neonatal pig: influence of age of piglet and molecular weight of markers. Biol. Neonate 1984, 46, 20-26.

Wittum TE, Perino LJ: Passive immune status at postpartum hour 24 and long-term health and performance of calves. Am. J. Vet. Res. 1995, 56, 11491154.

$X u R J$ : Development of the newborn GI tract and its relation to colostrum/milk intake: a review. Reprod. Fertil. Dev. 1996, 8, 35-48.

\section{Sammendrag \\ Optagelse af immunglobuliner fra kolostrum hos kompromitterede nyfødte husdyr.}

Dødeligheden af nyfødte husdyr er relativt høj $(\sim 10 \%)$ og sygdomsmodtageligheden bestemmes i høj grad af en tilstrækkelig passiv immunisering umiddelbart efter fødsel. I husdyr absorberes immunglobuliner fra kolostrum primært ved en uspecific endocytose af makromolekyler, men mange af detaljerne omkring absorptionsprocessernes forløb og deres totale ophør efter 1-2 dages fodring er stadig ukendte. Det samlede orale indtag af immunglobuliner har stor betydning, men såvel foder- som individ-afhængige faktorer spiller en væsentlig rolle for absorptionens effektivitet. Sådanne faktorer kan afgøre i hvilket omfang "kompromitterede" (dvs. umodne, vækst-retarderede eller på anden måde stressede) nyfødte husdyr opnår optimal immunisering. Tarmens evne til at optage immunglobuliner er således klart reduceret efter en for tidlig fødsel, og ligeledes hvis immunglobuliner skal absorberes fra en anden diæt end kolostrum fra samme art. Omvendt, er det ikke sandsynligt, at faktorer som lav fødselsvægt, in vitro produktion af embryoner samt selve fødselsprocessen har en negativ virkning på tarmens evne til at optage immunglobuliner fra kolostrum. Kendskab til såvel de ernærings- som individbetingede faktorer, som øver indflydelse på immunglobulinoptagelsen vil forbedre den kliniske behandling af "kompromitterede" nyfødte husdyr.

Contribution to 11. International Conference on Production Diseases in Farm Animals, 12-16 August 2001, The Royal Veterinary and Agricultural University, Frederiksberg, Denmark.

Reprints may be obtained from: Per T. Sangild, Department of Animal Science and And Animal Health, The Royal Veternary and Agricultural University, Grønnegårdsvej 3, DK-1870 Frederiksberg C, Denmark. E-mail: psa@kvl.dk, tel: +4535283065, fax: +4535283020. 